Abstract-The Atlantic surfclam (Spisula solidissima) supports a $\$ 29.2$-million fishery on the northeastern coast of the United States. Increasing global carbon dioxide $\left(\mathrm{CO}_{2}\right)$ in the atmosphere has resulted in a decrease in ocean $\mathrm{pH}$, known as ocean acidification (OA), in Atlantic surfclam habitat. The effects of OA on larval Atlantic surfclam were investigated for $28 \mathrm{~d}$ by using 3 different levels of partial pressure of $\mathrm{CO}_{2}\left(\rho \mathrm{CO}_{2}\right)$ :

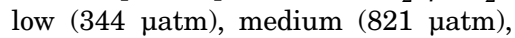
and high (1243 $\mu \mathrm{atm})$. Samples were taken to examine growth, shell height, time to metamorphosis, survival, and lipid concentration. Larvae exposed to a medium $\mathrm{\rho CO}_{2}$ level had a hormetic response with significantly greater shell height and growth rates and a higher percentage that metamorphosed by day 28 than larvae exposed to the high- and low-level treatments. No significant difference in survival was observed between treatments. Although no significant difference was found in lipid concentration, Atlantic surfclam did have a similar hormetic response for concentrations of phospholipids, sterols, and triacylglycerols and for the ratio of sterols to phospholipids, indicating that larvae may have a homeoviscous adaptation to $\mathrm{OA}$ at medium $\rho \mathrm{CO}_{2}$ levels. Our results indicate that larval Atlantic surfclam have some tolerance to slightly elevated $\rho \mathrm{CO}_{2}$ concentrations but that, at high $\rho \mathrm{CO}_{2}$ levels, they may be susceptible to OA.

Manuscript submitted 28 July 2020. Manuscript accepted 10 May 2020. Fish. Bull. 119:66-76 (2021).

Online publication date: 25 May 2021. doi: 10.7755/FB.119.1.8

The views and opinions expressed or implied in this article are those of the author (or authors) and do not necessarily reflect the position of the National Marine Fisheries Service, NOAA.

\title{
Effects of ocean acidification on larval Atlantic surfclam (Spisula solidissima) from Long Island Sound in Connecticut
}

\author{
Shannon L. Meseck (contact author) \\ Renee Mercaldo-Allen \\ Paul Clark \\ Catherine Kuropat \\ Dylan Redman \\ David Veilleux \\ Lisa Milke \\ Email address for contact author: shannon.meseck@noaa.gov \\ Milford Laboratory \\ Northeast Fisheries Science Center \\ National Marine Fisheries Service, NOAA \\ 212 Rogers Avenue \\ Milford, Connecticut 06460
}

The process of ocean acidification (OA) occurs when increased atmospheric carbon dioxide $\left(\mathrm{CO}_{2}\right)$ from anthropogenic activities (i.e., burning of fossil fuels and deforestation) is absorbed by ocean waters (Caldeira and Wickett, 2003; Raven et al. ${ }^{1}$; Doney et al., 2009). Consequently, concentrations of dissolved $\mathrm{CO}_{2}$ and bicarbonate ions $\left(\mathrm{HCO}_{3}^{-}\right)$ rise, while concentration of carbonate ions $\left(\mathrm{CO}_{3}{ }^{2-}\right), \mathrm{pH}$, and calcium carbonate saturation level $(\Omega)$ decline (Feely et al., 2004, 2010; Hönisch et al., 2012; Duarte et al., 2013). In recent years, the ocean's natural capacity for buffering, a process that normally occurs over a geologic timescale of 10,000-100,000 years, has been unable to keep pace with the rate of acidification (Hönisch et al., 2012; Zeebe, 2012; Zeebe et al., 2016), resulting in a global ocean $\mathrm{pH}$ drop of

\footnotetext{
${ }^{1}$ Raven, J., K. Caldeira, H. Elderfield, O. Hoegh-Guldberg, P. Liss, U. Riebesell, J. Shepherd, C. Turley, and A. Watson. 2005. Ocean acidification due to increasing atmospheric carbon dioxide. R. Soc. Policy Doc. 12/05, 57 p. [Available from website.]
}

0.1 . This ongoing shift in the carbonate system and corresponding decline in $\mathrm{pH}$ and $\Omega$ may affect the growth and survival of marine organisms.

Representative concentration pathways (RCPs) are used to predict future $\mathrm{CO}_{2}$ concentrations. By the year 2100, under the RCP 8.5 scenario (high emissions) used in climate modeling, $\mathrm{CO}_{2}$ levels will be $>1000$ uatm, and under the RCP 6.0 scenario, $\mathrm{CO}_{2}$ levels will be in the range of 720-1000 $\mu \mathrm{atm}$ (IPCC, 2014). Projected increases in $\mathrm{CO}_{2}$ by 2100 are expected to result in a reduction of $0.2-0.4$ in $\mathrm{pH}$ and in a $50 \%$ decline in aragonite saturation level $\left(\Omega_{\text {aragonite }}\right)$, a measure often used in relation to $\Omega$ because aragonite is a common form of calcium carbonate in ocean waters (Feely et al., 2004, 2010; Hartin et al., 2016). It has been predicted that, by the year $2300, \mathrm{CO}_{2}$ levels will be $>2000 \mu \mathrm{atm}$ and will correspond to an additional drop of 0.4 in $\mathrm{pH}$ (Feely et al., 2004, 2010; Hartin et al., 2016).

In a recent climate vulnerability assessment of fish and invertebrates on the continental shelf of the northeastern 
United States, shellfish species were categorized as highly susceptible to changing climate conditions (Hare et al., 2016). A conclusion of most of the research on effects of $\mathrm{OA}$ on marine mollusks has been that larval shellfish are more sensitive to OA than those in juvenile and adult stages (Gledhill et al., 2015; Siedlecki et al., 2021). In larval experiments with bay scallop (Argopecten irradians) (Talmage and Gobler, 2009; White et al., 2013), eastern oyster (Crassostrea virginica) (Miller et al., 2009; Talmage and Gobler, 2009; Gobler and Talmage, 2014), and northern quahog (Mercenaria mercenaria) (Green et al., 2004, 2009; Talmage and Gobler, 2009), reduced rates of survival and growth have been observed when larvae were exposed to acidification levels predicted to occur by 2100 . The findings of these studies indicate that an $\Omega_{\text {aragonite }}$ of $\sim 1.5$ results in physiological responses in marine bivalve species. These studies focused on bivalve species that reside in estuarine water, where changes in temperature, salinity, and partial pressure of $\mathrm{CO}_{2}\left(\mathrm{\rho CO}_{2}\right)$ can occur at daily rates (Feely et al., 2010; Dickinson et al., 2013; Duarte et al., 2013), and their results may not be applicable to coastal bivalve species.

A synthesis of available reports on ecological consequences of ocean and coastal acidification for species in the Northeast U.S. continental shelf large marine ecosystem has identified that to date little is known on how coastal bivalve species will respond to OA (Hare et al., 2016). Recently, juvenile Atlantic surfclam (Spisula solidissima) were found to have modified physiological processes at $\mathrm{CO}_{2}$ levels of RCP 8.5 scenario during a 12 -week exposure, with them being more sensitive than previously studied estuarine bivalves (i.e., oyster species and the blue mussel, Mytilus edulis) to increasing $\mathrm{\rho CO}_{2}$ levels (Pousse et al., 2020). The results of that study highlight the need to understand how larval Atlantic surfclam will respond to $\mathrm{OA}$ conditions.

Atlantic surfclam are planktonic larvae, transitioning to the pediveliger stage with a foot and "swimmingcrawling" behavior (Fay et al., 1983; Cargnelli et al., 1999). Larval Atlantic surfclam are concentrated near the thermocline and are transported horizontally by currents (Zhang et al., 2015, 2016; Chen et al., 2019). Along the coast of the northeastern United States, surface waters of the Atlantic Ocean and Gulf of Maine are characterized by high variability, both spatially (with increased acidification northward) and seasonally (with the lowest values during winter and the highest values in summer) (Biao et al., 2004; Wang et al., 2013; Xu et al., 2017; Goldsmith et al., 2019; Friedland et al., 2020). Records of carbonate chemistry of the subsurface water column in the Gulf of Maine have included $\Omega_{\text {aragonite }}$ levels that were lowest in the spring, ranging from 0.9 at the seafloor to 2.2 at the surface, and highest during the summer, ranging from 1.4 at the bottom to 2.6 at the surface, with a seasonal range of 1.0-2.0 (Wanninkhof et al., 2015; Wang, 2016). Wang et al. (2017) observed a decrease of 0.01 in $\Omega_{\text {aragonite }}$ for every $1 \mu \mathrm{mol} / \mathrm{kg}$ increase in dissolved inorganic carbon (DIC), similar to what has been observed in the open ocean (Bates et al., 2014). Recently, an oceanographic glider, an autonomous underwater vehicle, was used off the coast of New Jersey to measure subsurface pH levels, which ranged from 7.91 to 8.20 , and to measure $\Omega_{\text {aragonite, }}$ which ranged from 1.5 to 2.2 with higher readings at the surface (Saba et al., 2019).

Although there is evidence of increasing $\rho \mathrm{CO}_{2}$ concentrations in waters where larval Atlantic surfclam are concentrated during development, data are sparse at the thermocline, and the processes and drivers of these changes are not understood fully (Boehme et al., 1998; Wang et al., 2017). The limited data that is available, combined with model projections for the entire region, indicate that some areas in the region where Atlantic surfclam concentrate will reach global levels of $\rho \mathrm{CO}_{2}$ predicted for 2100 as early as 2030-2050 (Ekstrom et al., 2015; Siedlecki et al., 2021).

Characterizing the effects of OA on Atlantic surfclam is complex in part because of the presence of 2 subspecies along the coast of the northeastern United States (Hare and Weinberg, 2005). Both subspecies are referred to as Atlantic surfclam; however, there are physiological differences between the 2 subspecies. The more northern subspecies, $S$. s. solidissima, is larger in size (length: $150-200 \mathrm{~mm}$ ) and lives longer (25-30 years) than the more southern subspecies, S. s. similis, which ranges in length from 76 to $122 \mathrm{~mm}$ and lives for 4.0-5.5 years (Walker and O'Beirn, 1996; Weinberg and Helser, 1996). The subspecies differ in geographic range, with the northern subspecies of Atlantic surfclam found from the Gulf of Saint Lawrence in Canada south to Cape Hatteras in North Carolina and with the southern subspecies thought to be distributed primarily in shallow nearshore environments along the coast of Cape Hatteras and in waters of the Gulf of Mexico off the coast of the southeastern United States.

The Connecticut Bureau of Aquaculture identifies Atlantic surfclam in Long Island Sound (LIS) as S. solidissima, but results of DNA analysis indicate that $S$. s. simi$l i s$, although it is considered the more southern subspecies, is located primarily off the coast of Massachusetts; there also is a confirmed population of the southern subspecies in waters of New York in LIS (Hare et al., 2010). Results of a recent survey conducted by the NOAA Northeast Fisheries Science Center indicate that the southern subspecies of Atlantic surfclam may be shifting northward because of increased water temperatures (NEFSC, 2017). The Mid-Atlantic Fishery Management Council in fiscal year 2019 solicited studies to examine whether there has been an expansion of the distribution of the southern subspecies of Atlantic surfclam into the habitat of the northern subspecies, recognizing there are potential implications for stock assessments if multiple species that are genetically different are managed together.

Until the geographical distribution of both subspecies is better understood, we will make no assumption of which subspecies was used in our experiment and will refer to the brood stock and larvae of Atlantic surfclam in our study as S. solidissima. This choice is consistent with current management of the commercial industry for Atlantic surfclam as a single fishery, with harvesting concentrated 
in estuarine waters of LIS, nearshore coastal waters (0-5 km [0-3 mi]) of New Jersey and New York, and offshore waters along the Atlantic coast from New Jersey to Virginia. Highly valued, the Atlantic surfclam fishery generated more than $\$ 29.2$ million in revenue during 2019 (National Marine Fisheries Service, commercial fisheries landings database, available from website).

Changes in environmental conditions of the habitat of Atlantic surfclam are comparable to changes in the open ocean, with seasonal variability in $\Omega_{\text {aragonite }}$ near or below the physiological threshold of 1.5 identified for other bivalves, yet there have been no studies examining how larval Atlantic surfclam respond to increasing $\rho \mathrm{CO}_{2}$ levels. On the basis of the RCP 6.0 and RCP 8.5 scenarios (IPCC, 2014) and current conditions of the habitat of Atlantic surfclam, our study investigated the effect of low, medium, and high levels of $\mathrm{\rho CO}_{2}(344,821$, and $1243 \mu \mathrm{atm})$ on growth, mortality, and metamorphosis of larval Atlantic surfclam. We hypothesized that larvae of Atlantic surfclam might have reduced rates of survival and growth and experience longer times to metamorphosis with increased $\rho \mathrm{CO}_{2}$ concentrations. We also hypothesized that allocation of energetic resources in larval Atlantic surfclam, measured by using lipid concentrations, might change in response to variations in carbonate chemistry.

\section{Materials and methods}

\section{Spawning}

Adult brood stock of Atlantic surfclam were collected from 2 locations in LIS. In 2014, 32 clam were caught on 4 November from Stratford, Connecticut, and 75 individuals were collected on 6 November from Norwalk, Connecticut, from on board a commercial shellfish boat. The brood stock acclimated for $169 \mathrm{~d}$ at the Milford Laboratory $\left(41^{\circ} 12^{\prime} 43.82^{\prime \prime} \mathrm{N}, 73^{\circ} 3^{\prime} 12.96^{\prime \prime} \mathrm{W}\right)$ of the Northeast Fisheries Science Center in a flow-through seawater system $\left(16^{\circ} \mathrm{C}\right.$ [standard deviation 3]) delivering natural seston that was supplemented with a drip of cultured Tetraselmis chui (strain PLY429). Brood stock were conditioned for spawning following the protocol outlined in Goldberg (1989). On 22 April 2015, 30 scrubbed Atlantic surfclam from both collection sites were placed in a spawning table filled with 10 - $\mu \mathrm{m}$-filtered seawater. To induce spawning, seawater temperature was increased by $2^{\circ} \mathrm{C}$ every $30 \mathrm{~min}$, to a maximum of $26^{\circ} \mathrm{C}$. Upon release of gametes, male and female Atlantic surfclam were placed into separate glass dishes. Gametes were collected from 7 females and 5 males, and then pooled eggs were fertilized with pooled sperm in ambient seawater, yielding a total fertilized egg count of 81.6 million.

After fertilization, 30 embryos/mL were added to each of 9 clean 15-L buckets containing $10 \mathrm{~L}$ of 0.35 - $\mu \mathrm{m}$-filtered seawater that had been pumped directly from Milford Harbor and bubbled with $\mathrm{CO}_{2}$ to reach target conditions (described in the "Experimental design" section).
Larvae were fed after $24 \mathrm{~h}$ with cultured Tisochrysis lutea (isolator number: T-ISO) at an algal density of 50,000 cells/mL (Goldberg, 1989). Every Monday, Wednesday, and Friday, the larvae in buckets were screened, buckets were cleaned, and water in the buckets was replaced with preconditioned water for each $\mathrm{\rho CO}_{2}$ treatment level. Cleaning helped reduce ciliate levels that were present in all treatments. Larval experiments were conducted from 22 April through 20 May 2015.

\section{Experimental design}

Nine buckets were placed in a temperature-controlled water table (Table 1). The target $\rho \mathrm{CO}_{2}$ levels $(\sim 400, \sim 800$, and $~ 1200 \mu \mathrm{atm}$ ) were chosen on the basis of RCP scenarios for future $\mathrm{CO}_{2}$ concentrations in the region and the 3 levels identified in the guide to best practices for $\mathrm{OA}$ research and data reporting (Riebesell et al., 2011). Compressed air was passed through a PureGas ${ }^{2} \mathrm{CO}_{2}$ absorber (Altec Air, Broomfield, CO) before being delivered to GFC mass flow controllers for air and carbon dioxide (Aalborg Instruments and Controls, Orangeburg, NY). The $\mathrm{CO}_{2-}$ stripped air was mixed with research-grade $\mathrm{CO}_{2}$ to create and maintain 3 target $\rho \mathrm{CO}_{2}$ treatment levels and was distributed to 3 replicate buckets per treatment at a moderate aeration rate $(12 \mathrm{~L} / \mathrm{min})$ that is routinely used in bivalve culture (Loosanoff and Davis, 1963; Bayne, 1965).

\section{Biological sampling}

Larvae samples for examining size, survival, metamorphosis, and lipids were taken on a volume basis weekly when buckets were cleaned. Briefly, larvae were screened on a nylon mesh sieve (40-150 $\mu \mathrm{m})$ and concentrated in a 100-mL graduated cylinder. A subsample of $1 \mathrm{~mL}$ was removed from the graduated cylinder and preserved in a $1 \%$ solution of buffered formalin for measurement of shell heights (maximum length, from anterior to posterior, parallel to the hinge; number of samples $[n]=50$ larvae). When the experiment began on 22 April 2015, 4 samples were taken for initial measurements of size, and triplicate samples from each bucket were obtained and preserved weekly for size measurements and for determination of the percentages of all larvae in the sample that had died (percent mortality) and that had undergone metamorphosis by using an Olympus inverted microscope (Olumpus IX51, Olympus Corp., Tokyo, Japan) and the software ImageJ, vers. 1.49 (Rasband, 2015).

Lipid samples were obtained at the end of the experiment on day 28 . Known volumes $(0.3-0.5 \mathrm{~mL})$ of concentrated Atlantic surfclam were collected and placed in glass tubes that had been prerinsed with methanol and chloroform. Samples were stored in $2 \mathrm{~mL}$ of chloroform, purged of air with nitrogen gas, and held at $-80^{\circ} \mathrm{C}$ until analysis

\footnotetext{
${ }^{2}$ Mention of trade names or commercial companies is for identification purposes only and does not imply endorsement by the National Marine Fisheries Service, NOAA.
} 


\section{Table 1}

Carbonate chemistry and environmental characteristics measured at low, medium, and high levels of partial pressure of carbon dioxide $\left(\mathrm{CO}_{2}\right)$ and used to investigate the effect of $\rho \mathrm{CO}_{2}$ levels on laboratory-reared larval Atlantic surflclam (Spisula solidissima) in 2015. The variables include mean measured $\mathrm{pH}$ (seawater scale, $\mathrm{pH}$ measured at $20^{\circ} \mathrm{C}$ ), $\mathrm{pH}$ in situ (seawater scale, $\mathrm{pH}$ at the temperature of the experiment), temperature $\left({ }^{\circ} \mathrm{C}\right)$, salinity, $\rho \mathrm{CO}_{2}(\mu \mathrm{atm})$, total dissolved inorganic carbon (DIC) $(\mu \mathrm{mol} / \mathrm{kg}$ ), and saturation levels of calcite $\left(\Omega_{\text {calcite }}\right)$ and aragonite $\left(\Omega_{\text {aragonite }}\right)$ for the duration of the experiment. Values are means with standard errors of the mean in parentheses. Asterisks (*) indicate values that were measured directly and not calculated by using the program CO2SYS. The adult brood stock used to rear individuals for this study were collected in 2014 from Long Island Sound near Stratford and Norwalk, Connecticut.

\begin{tabular}{lccc}
\hline & \multicolumn{3}{c}{ Treatment level of $\rho \mathrm{CO}_{2}$} \\
\cline { 2 - 4 } Characteristic & Low & Medium & High \\
\hline pH measured & $7.972(0.003)$ & $7.629(0.003)$ & $7.462(0.003)$ \\
pH in situ & $8.073(0.003)$ & $7.734(0.003)$ & $7.568(0.003)$ \\
Temperature $^{*}$ & $18.8(0.1)$ & $18.9(0.1)$ & $18.9(0.1)$ \\
Salinity $^{*}$ & $25.72(0.08)$ & $25.73(0.08)$ & $25.73(0.08)$ \\
$\rho_{\text {CO }}{ }_{2}$ & $343.9(5.9)$ & $820.8(6.0)$ & $1242.9(5.9)$ \\
$\mathrm{DIC}^{*}$ & $1800.66(2.35)$ & $1903.74(2.39)$ & $1953.32(2.37)$ \\
$\Omega_{\text {calcite }}$ & $3.46(0.01)$ & $1.74(0.02)$ & $1.22(0.02)$ \\
$\Omega_{\text {aragonite }}$ & $2.18(0.01)$ & $1.09(0.01)$ & $0.77(0.01)$ \\
& & &
\end{tabular}

was to begin. Samples were shipped overnight to the Memorial University of Newfoundland for lipid analysis, where they were extracted by following a modified Folch procedure (Parrish, 1999), and lipid classes were identified by using a Chromarod-Iatroscan system for thin-layer chromatography and flame ionization detection (Mark V, Iatron Laboratories, Tokyo, Japan).

\section{Carbonate chemistry measurements}

Seawater samples were collected from each bucket for carbonate chemistry measurements immediately before and after water changes $(n=63)$. One sample per bucket was obtained by placing a tube fit with an airstone into the bottom of each bucket and filling 500-mL polypropylene collection bottles to overflow (1.5 times) by using a peristaltic pump. The airstone ensured that larvae and phytoplankton were not collected with the seawater samples. Samples were analyzed immediately for $\mathrm{pH}$ and DIC.

Total $\mathrm{pH}$ was determined colorimetrically by using m-Cresol purple indicator dye (Sigma-Aldrich, St. Louis, MO) (Dickson and Goyet ${ }^{3}$ ) with an Ocean Optics 2000+ UV spectrometer (Ocean Insight, Orlando, FL). All

\footnotetext{
${ }^{3}$ Dickson, A. G., and C. Goyet (eds.). 1994. Handbook of methods for the analysis of the various parameters of the carbon dioxide system in sea water, version 2. U.S. Dep. Energy, Oak Ridge Natl. Lab., Carbon Dioxide Inf. Anal. Cent. ORNL/CDIAC-74, 180 p. [Available from website.]
}

samples were analyzed for DIC without the addition of preservatives on a DIC analyzer (AS-C3, Apollo SciTech, LLC, Newark, DE). To ensure precision, replicate samples $(n=5)$ of certified reference material also were analyzed, resulting in 1 standard deviation of $2.7 \mu \mathrm{mol} / \mathrm{kg}$ for total DIC replicates and of 0.0014 for total $\mathrm{pH}$. The DIC instrument was part of a previous international, interlaboratory exercise for comparison of DIC in test seawater samples with low and high $\mathrm{CO}_{2}$ levels; DIC during our study measured within $0.5 \%$ of assigned values (Bockmon and Dickson, 2015). Seawater temperature and salinity were measured daily by using a YSI Model 85 handheld oxygen, conductivity, salinity, and temperature system (YSI, Inc., Yellow Springs, OH). Dissolved inorganic carbon and $\mathrm{pH}$ values were entered into the program CO2SYS (Pierrot et al., 2006) to calculate $\rho \mathrm{CO}_{2}$ (in microatmospheres), calcite saturation level $\left(\Omega_{\text {calcite }}\right)$, and $\Omega_{\text {aragonite }}$ by using the following constants: $K_{1}^{\prime}, K_{2}^{\prime}$ from Mehrbach et al. (1973) and refit by Dickson and Millero (1987), $K$ hydrogen sulfate from Dickson (1990), and total boron from Uppström (1974).

\section{Statistical analyses}

The software Statgraphics Plus (vers 17.1.12, Statgraphics Technologies, The Plains, VA) was used for all statistical analyses. All data were checked for normality by using the Shapiro-Wilk test, with a significance level of 0.05 , and for equal variance prior to statistical analysis. 
Linear growth during the larval stage (Powell et al., 2002; Pace et al., 2006) was estimated with this equation:

$$
y=m x+b,
$$

where $y=$ length (in micrometers);

$m=$ slope (in micrometers per day);

$x=$ time (in days); and

$b=$ intercept (initial length in micrometers).

For each bucket, mean rates of shell growth (in micrometers per day, with standard errors of the mean [SE]) were determined by the slope of shell length versus age. An analysis of covariance was used to compare the regression lines and to discern if they were statistically significant $(P<0.05)$. If a significant difference was detected between slopes, further examination was done by using analysis of variance. Data for lipid concentration (in micrograms per gram of wet weight), for percent lipid (lipid concentration divided by total lipid concentration multiplied by100) and for percentages of all larvae in the sample that survived and that had successfully completed metamorphosis were collected at the end of the experiment. All data collected as percentages were transformed with arcsine (square root) prior to statistical analysis and prior to analysis of variance. Least square difference was used to determine different homogeneous groups. For all statistical analyses, degrees of freedom equaled 6 .

\section{Results}

\section{Seawater physicochemical variables}

Carbonate chemistry and environmental variables in the $3 \rho \mathrm{CO}_{2}$ treatments are shown in Table 1 . Values for measured pH were 7.972 (SE 0.003), 7.629 (SE 0.003), and 7.462 (SE 0.003) for the treatments with low, medium, and high levels of $\rho \mathrm{CO}_{2}$, respectively. Values of DIC were $1800.66 \mu \mathrm{mol} / \mathrm{kg}$ (SE 2.35) for the low- $\rho \mathrm{CO}_{2}$ treatment, $1903.74 \mu \mathrm{mol} / \mathrm{kg}$ (SE 2.39) for the medium- $\rho \mathrm{CO}_{2}$ treatment, and $1953.32 \mu \mathrm{mol} / \mathrm{kg}$ (SE 2.37) for the high- $\rho \mathrm{CO}_{2}$ treatment. Other carbonate system characteristics $\left(\rho \mathrm{CO}_{2}\right.$,

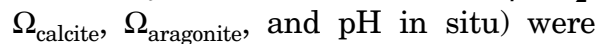
calculated at the in situ temperature and are reported in Table 1 . The calculated levels of $\mathrm{\rho CO}_{2}$ were 343.9 uatm (SE 5.9), $820.8 \mu \mathrm{atm}$ (SE 6.0), and $1242.9 \mu \mathrm{atm}$ (SE 5.9) for the 3 treatments with different experimental conditions. There was a significant difference in $\mathrm{\rho CO}_{2}(F$ ratio $=2945$, $P<0.01)$ between the low-, medium-, and high- $\rho \mathrm{CO}_{2}$ treatments. Mean seawater temperature $\left(18.9^{\circ} \mathrm{C}\right.$ [SE 0.1]) and salinity (25.73 [SE 0.08]) remained stable throughout the study period (Table 1 ).

\section{Larval growth, survival, metamorphosis, and lipids}

Significant differences were observed in the final shell height of Atlantic surfclam from fertilization to metamorphosis at the conclusion of the experiment, with greater shell height (in micrometers) for individuals in the medium- $\rho \mathrm{CO}_{2}$ treatment than for those in the treatments with low and high $\rho \mathrm{CO}_{2}$ levels $(F$ ratio $=6.986, P=0.03$; Fig. 1). The specimens in the medium- $\mathrm{CCO}_{2}$ treatment had a final shell height that measured $13 \%$ larger than those in the the high- and low- $\rho \mathrm{CO}_{2}$ treatments, but there was no difference in final shell height between the individuals exposed to low and high $\mathrm{\rho CO}_{2}$ levels. Larvae in the treatment with a medium $\mathrm{\rho CO}_{2}$ level had a mean growth rate of $7.16 \mu \mathrm{m} / \mathrm{d}$ (SE 0.25$)$ that was significantly greater $(F$ ratio $=5.84, P=0.04), 15 \%$ higher, than the mean rate observed for larvae in the low- $\rho \mathrm{CO}_{2}$ treatment, $8.26 \mu \mathrm{m} / \mathrm{d}$ (SE 0.25). Growth rates of larvae under the high- $\rho \mathrm{CO}_{2}$ treatment, with a mean rate of $7.25 \mu \mathrm{m} / \mathrm{d}$ (SE 0.25), were similar to those of larvae in the low- $\rho \mathrm{CO}_{2}$ treatment.

Although larval survival did not differ significantly ( $F$ ratio $=3.23, P=0.17$ ) between treatments, survival rates in the medium- $\rho \mathrm{CO}_{2}$ treatment (29\% [SE 5]) were twice those observed in the treatments with high (17\% [SE 5]) and low (11\% [SE 5]) $\rho \mathrm{CO}_{2}$ levels. After $28 \mathrm{~d}$, significantly more larvae $(F$ ratio $=12.89, P<0.01)$ in the medium- $\rho \mathrm{CO}_{2}$ treatment successfully completed metamorphosis $(88 \%$ [SE 1]) than in the low- and high- $\rho \mathrm{CO}_{2}$ treatments, at 65\% (SE 6) and 61\% (SE 5), respectively. There was no

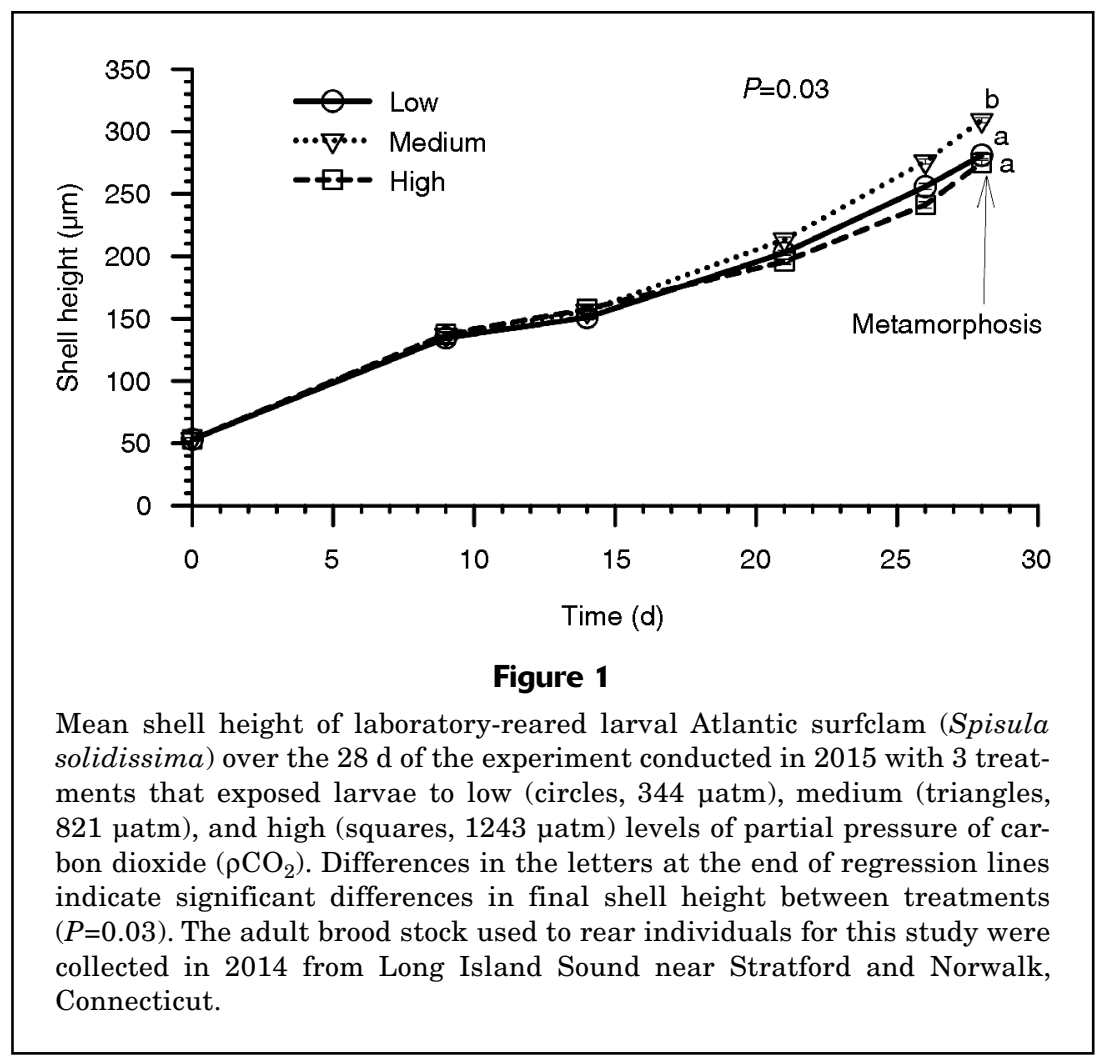


significant difference in metamorphosis of Atlantic surfclam between the low- and high- $\rho \mathrm{CO}_{2}$ treatments.

Lipid concentration and percent lipid measured at the end of the experiment indicate variable responses to the tested OA conditions (Table 2). Phospholipids and triacylglycerols constituted a large portion of the total lipid concentration (58-69\%) for all treatments, and there were no significant differences in these characteristics between treatments $(F$ ratio $=1.612, P=0.28)$. There was no significant difference in the sterol-to-phospholipid ratio $(F$ ratio $=0.77, P=0.77)$.

\section{Discussion}

Atlantic surfclam from LIS performed better at $\rho \mathrm{CO}_{2}$ levels predicted for the RCP 6.0 scenario than at current levels or levels predicted for the RCP 8.5 scenario, resulting in a hormetic (U-shaped) response for growth, larval shell height, and percentage of larvae that successfully completed metamorphosis. This response is atypical of estuarine bivalve larvae in OA experiments of previous studies; larvae in those studies had negative responses at $\mathrm{\rho CO}_{2}$ levels reported for the RCP 6.0 and RCP 8.5

\section{Table 2}

Final lipid concentrations (in micrograms per gram of wet weight) and percent lipid (lipid concentration divided by total lipid concentration multiplied by 100) for laboratory-reared larval Atlantic surfclam (Spisula solidissima) at the end of the experiment (after $28 \mathrm{~d}$ ) conducted in 2015 with 3 treatments that

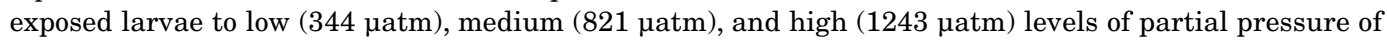
carbon dioxide $\left(\mathrm{\rho CO}_{2}\right)$. Values with different superscript letters are significantly different $(P<0.05)$. Standard errors of the mean are provided in parentheses. For all analyses, degrees of freedom equaled 6 . The adult brood stock used to rear individuals for this study were collected in 2014 from waters of Connecticut in Long Island Sound. ND=not detected.

\begin{tabular}{|c|c|c|c|c|c|}
\hline \multirow[b]{2}{*}{ Lipid } & \multicolumn{3}{|c|}{ Lipid concentration $(\mu \mathrm{g} / \mathrm{g})$ by treatment level of $\rho \mathrm{CO}_{2}$} & \multirow[b]{2}{*}{$F$ ratio } & \multirow[b]{2}{*}{$P$} \\
\hline & Low & Medium & High & & \\
\hline Acetone mobile polar lipids & $34.20(18.44)$ & $95.94(18.44)$ & $80.23(18.44)$ & 3.03 & 0.12 \\
\hline Alcohols & ND & ND & $4.22(2.43)$ & 1.00 & 0.42 \\
\hline Diacylglycerols & ND & ND & ND & ND & ND \\
\hline Ethyl esters & $1.91(1.10)$ & ND & ND & 1.00 & 0.42 \\
\hline Ethyl ketones & $15.07(4.69)^{\mathrm{a}}$ & $50.43(4.69)^{\mathrm{b}}$ & $37.63(4.69)^{\mathrm{a}, \mathrm{b}}$ & 5.48 & 0.04 \\
\hline Free fatty acids & $16.49(4.90)$ & $22.86(4.90)$ & $24.36(4.98)$ & 0.73 & 0.52 \\
\hline Glycerol ethers & ND & ND & ND & ND & ND \\
\hline Hydrocarbons & $3.42(0.96)^{\mathrm{a}}$ & $8.23(1.27)^{\mathrm{b}}$ & $5.43(0.54)^{\mathrm{a}, \mathrm{b}}$ & 6.11 & 0.035 \\
\hline Methyl esters & ND & ND & ND & ND & ND \\
\hline Methyl ketones & $15.07(8.16)$ & $50.43(8.16)$ & $37.63(8.16)$ & 4.81 & 0.06 \\
\hline Phospholipids & $117.43(52.14)$ & $219.68(52.14)$ & $199.07(52.14)$ & 1.08 & 0.40 \\
\hline Sterols & $13.26(5.04)$ & $32.24(5.04)$ & $24.54(5.04)$ & 3.59 & 0.09 \\
\hline Steryl wsters/wax esters & ND & $4.65(2.68)$ & $1.36(2.68)$ & 0.79 & 0.49 \\
\hline Triacylglycerols & $105.82(89.66)$ & $342.17(89.66)$ & $220.12(89.66)$ & 1.74 & 0.25 \\
\hline Sterol-phospholipid ratio & $0.14(0.02)$ & $0.15(0.02)$ & $0.13(0.02)$ & 0.77 & $<0.01$ \\
\hline \multirow[t]{2}{*}{ Total } & $316.12(173.88)$ & $806.35(173.88)$ & $613.01(173.88)$ & 2.02 & 0.21 \\
\hline & \multicolumn{3}{|c|}{ Percent lipid by treatment level of $\rho \mathrm{CO}_{2}$} & & \\
\hline Lipid & Low & Medium & High & $F$ ratio & $P$ \\
\hline Acetone mobile polar lipids & $15.68(2.85)$ & $11.52(2.85)$ & $14.32(2.85)$ & 0.42 & 0.68 \\
\hline Alcohols & ND & ND & $1.51(0.87)$ & 1.0 & 0.83 \\
\hline Diacylglycerols & ND & ND & ND & ND & ND \\
\hline Ethyl esters & $1.39(0.80)$ & ND & ND & 1.00 & 0.83 \\
\hline Ethyl ketones & $3.59(0.78)$ & $3.96(0.78)$ & $2.46(0.78)$ & 1.12 & 0.39 \\
\hline Free fatty acids & $7.04(1.03)$ & $2.82(1.03)$ & $4.37(1.03)$ & 4.52 & 0.06 \\
\hline Glycerol ethers & ND & ND & ND & ND & ND \\
\hline Hydrocarbons & $1.60(0.46)$ & $1.11(0.46)$ & $1.07(0.46)$ & 0.31 & 0.74 \\
\hline Methyl esters & ND & ND & ND & ND & ND \\
\hline Methyl ketones & $4.76(0.55)$ & $6.48(0.55)$ & $6.47(0.55)$ & 3.72 & 0.09 \\
\hline Phospholipids & $35.35(2.38)$ & $28.11(2.38)$ & $34.17(2.38)$ & 2.74 & 0.14 \\
\hline Sterols & $4.81(0.59)$ & $4.08(0.59)$ & $4.42(0.59)$ & 0.37 & 0.71 \\
\hline Steryl esters/wax esters & ND & $0.43(0.26)$ & $0.28(0.26)$ & 1.38 & 0.32 \\
\hline Triacylglycerols & $22.79(6.30)$ & $41.50(6.30)$ & $30.95(6.30)$ & 1.57 & 0.28 \\
\hline
\end{tabular}


scenarios (Miller et al., 2009; Talmage and Gobler, 2009; White et al., 2013; Waldbusser et al., 2015). In studies of other clam species, increasing $\rho \mathrm{CO}_{2}$ above current levels resulted in linear decreases in growth and shell size of softshell clam (Mya arenaria) (Green et al., 2009, 2013; Clements and Hunt, 2014), northern quahog (Talmage and Gobler, 2009; Gobler and Talmage, 2014), eastern oyster (Talmage and Gobler, 2009), and Pacific oyster (C. gigas) (Waldbusser and Salisbury, 2014; Waldbusser et al., 2015). However, no effects at $\rho \mathrm{CO}_{2}$ concentrations of the RCP 8.5 scenario have been reported for the Olympia oyster (Ostrea lurida) (Waldbusser et al., 2016), Antarctic bivalve (Laternula elliptica) (Bylenga et al., 2015), or blue mussel (Gazeau et al., 2013). A hormetic response to OA exposure in bivalves, although not often reported, was recently reported for juvenile Atlantic surfclam (Pousse et al. 2020) and has been noted in other marine species, including copepod ( $\mathrm{Li}$ and Gao, 2012; Thor and Oliva, 2015) and finfish (Miller et al., 2013, 2016) species.

Other bivalve species may experience a hormetic response, but it may be masked by the $\mathrm{\rho CO}_{2}$ levels chosen for other experiments, choices that can result in only a decrease being observed. For example, in a repeat study conducted in 2014 with eastern oyster by using a finer exposure resolution than that in our study, a maximal hormetic response at a $\mathrm{\rho CO}_{2}$ of 380 uatm was found for growth and percentage of larvae that completed metamorphosis (Gobler and Talmage, 2014). Unlike larvae of estuarine bivalve species, the larval Atlantic surfclam in our experiment were able to tolerate moderate OA levels. Future research should include a finer exposure resolution to determine the width of hormetic response in larvae of Atlantic surfclam.

In previous studies conducted with estuarine bivalves, larvae of most species were more sensitive to increased $\mathrm{\rho CO}_{2}$ than juveniles or adults. For example, for eastern oyster exposed to conditions of the RCP 6.0 scenario, larvae had reduced rates of growth rates and survival and a lower percentage of larvae completed metamorphosis (Talmage and Gobler, 2009), and for juveniles no significant difference was observed in growth at the $\mathrm{\rho CO}_{2}$ level of the RCP 6.0 scenario (Dickinson et al., 2012) or levels greater than that of the RCP 8.5 scenario (1700 ratm; Young and Gobler, 2018). For adult eastern oyster in other studies, no effects on growth or gaping were observed at $\mathrm{\rho CO}_{2}$ levels as high as 8000 uatm (Clements et al., 2017, 2018). A similar trend has been observed for blue mussel with larvae being more sensitive than adults (Thomsen et al., 2017).

Even though the results of this study were surprising, with increased growth at $\mathrm{\rho CO}_{2}$ levels predicted for the RCP 6.0 scenario, growth decreased at levels predicted for the RCP 8.5 scenario. Results of an experiment with juveniles of this subspecies indicate a similar hormetic response to that of larvae in our study (Pousse et al., 2020). Pousse et al. (2020) found metabolic depression in juvenile Atlantic surfclam exposed to $\rho \mathrm{CO}_{2}$ levels of $1350 \mu \mathrm{atm}$, making them more susceptible than Pacific oyster (Lannig et al., 2010) and blue mussel (Thomsen and Melzner,
2010). The larval Atlantic surfclam in our study were not exposed to the higher levels of $\rho \mathrm{CO}_{2}$ used on juveniles in the Pousse et al. (2020) study, but it would be interesting to determine when metabolic depression occurred in larvae considering the similar trends observed between these 2 studies. We cannot explain why larval and juvenile Atlantic surfclam may behave similarly or why larval Atlantic surfclam appear to tolerate higher levels of $\rho \mathrm{CO}_{2}$ than larvae of some other estuarine species like the eastern oyster; however, a possible reason may relate to how Atlantic surfclam allocate energy for growth and development. Bioenergetic studies, including those that include dynamic energy budget modeling, would provide insight into whether the small changes in growth observed in our study and in the study of Pousse et al. (2020) would have a long-term effect over the time period required for Atlantic surfclam to reach harvest size and would help to clarify variation in responses between bivalve species.

Parsons (2001) suggests that a hormetic response may reflect evolutionary adaptation of metabolic systems to environmental variables and may link to Darwinian fitness; however, there is little quantitative evidence currently available to confirm this hypothesis. Recent research on the response of bivalve larvae to OA has focused on population-level responses and the potential for evolutionary adaptation. Increased growth of larval Atlantic surfclam at elevated $\mathrm{\rho CO}_{2}$ concentrations during our study may reflect adaptation of adults in the source population. The wild adults used in this study were exposed to conditions during the summer in LIS, where in situ sediment levels of $\mathrm{\rho CO}_{2}$ can periodically range from 689 to 1828 uatm (Perry et al., 2015; Meseck et al., 2018; Snyder et al., 2019). Researchers have found that survival of larvae varied significantly between populations of the Sydney rock oyster (Saccostrea glomerata) (Parker et al., 2011) and Chilean mussel (M. chilensis), on the basis of the history of adult exposure to OA (Duarte et al., 2015). These findings indicate potential physiological and metabolic adaptations of shellfish populations to OA conditions.

It was beyond the scope of this study to determine the ability of Atlantic surfclam to adapt and evolve to shifting environmental conditions; however, future evolutionary adaptation studies should include both subspecies of Atlantic surfclam. There is an evolutionary divergence of $13.9 \%$ between the northern and southern subspecies, indicating long-term reproductive isolation of these subspecies (Hare and Weinberg, 2005; Hare et al., 2010) that may have allowed each to develop differential tolerances to OA conditions. A comparison between specimens of the 2 subspecies from the same location, exposed to increasing $\mathrm{\rho CO}_{2}$, might resolve whether there is an evolutionary divergence in $\mathrm{OA}$ tolerance between the subspecies, and the results of such an investigation could support more refined management of populations of Atlantic surfclam in New England.

Slower growth rates and smaller shell height in larvae from the high- and low- $\rho \mathrm{CO}_{2}$ treatments indicate that suboptimal conditions for larval Atlantic surfclam may stimulate a shift in allocation of energetic resources 
away from allometric growth toward maintenance of metabolic or physiological homeostasis. Ocean acidification in marine environments can cause invertebrates to slow metabolism and may result in reduced growth and smaller body size (Pörtner et al., 2005; Gobler and Talmage, 2014). The hormetic response we observed in growth and time to metamorphosis of Atlantic surfclam may result from energetic changes reflected in lipid metabolism. Although there was no significant difference between the lipid levels in specimens among treatments, there was a consistent trend in the concentrations of phospholipids, sterols, and triacylglycerols and in the ratio of sterols to phospholipids, with the same hormetic response as that observed for growth. The trend we observed in these lipid levels among treatments may indicate an adaptive response of membranes to different environmental conditions, including temperatures and pressures (Crockett, 1998; Pernet et al., 2006, 2007), a process known as homeoviscous adaptation (HVA).

Homeoviscous adaptation in other marine organisms has been reported previously as an adaptive response to OA (Turk et al., 2007; Bennett et al., 2018). Slight decreases in phospholipid, sterol, and triacylglycerol levels and in the sterol-to-phospholipid ratio at low and high $\rho \mathrm{CO}_{2}$ levels, like those observed in our study, may provide a metabolically less expensive and energy-conserving mechanism to reduce expenditure of adenosine triphosphate (Crockett, 1998) that facilitates use of different ion exchange pathways (Kusumi et al., 1986). Pousse et al. (2020) found an HVA response in respiration rates and food selection efficiency of juvenile Atlantic surfclam. Further research on how HVA pathways are used in larvae under OA conditions should be pursued with the additional measurements of respiration rate, feeding rate, and scope for growth to help determine if OA can facilitate different metabolic pathways.

Movement of populations of Atlantic surfclam northward and into deeper water can be attributed to warming temperatures (Weinberg, 2005; Munroe et al., 2016). Limited $\rho \mathrm{CO}_{2}$ data, combined with modeling results, indicate that decreases in $\mathrm{pH}$ and $\Omega_{\text {aragonite }}$ occur in the areas to which Atlantic surfclam are moving (Wang, 2016; Saba et al., 2019; Friedland et al., 2020; Siedlecki et al., 2021). This study focused on only the $\mathrm{\rho CO}_{2}$ levels predicted for the RCP 6.0 and RCP 8.5 scenarios; we did not look at the role of increasing temperature. Under the RCP 6.0 and RCP 8.5 scenarios, increases in temperature are expected to occur concurrently with increased $\mathrm{\rho CO}_{2}$ levels. Future research should include examination of the response of Atlantic surfclam to OA under different temperatures to determine if the combined effects of temperature and $\mathrm{OA}$ changes their tolerance to $\mathrm{\rho CO}_{2}$ concentrations.

Atlantic surfclam can live up to 35 years and become harvestable within 5-7 years, and this study focused on a short portion of their lifespan. More information about the $\rho \mathrm{CO}_{2}$ levels experienced by larval, juvenile, and adult Atlantic surfclam during their lifetime is needed to better define the range of $\mathrm{\rho CO}_{2}$ concentrations on which future studies should focus. Further research should emphasize the bioenergetic pathways governing larval response to $\mathrm{OA}$ and address adaption and evolution by including genetic analysis. Finally, incorporating increased $\rho \mathrm{CO}_{2}$ levels into future research would provide information beneficial to fisheries management efforts.

\section{Acknowledgments}

The authors thank R. Goldberg, D. Perry, and J. Rose for technical assistance, J. Bloom from Copps Island Oysters and D. Carey of the Connecticut Department of Agriculture, Bureau of Aquaculture, for collection of brood stock of Atlantic surfclam, and the Northeast Fisheries Science Center for funding.

\section{Literature cited}

Bates, N. R., Y. M. Astor, M. J. Church, K. Currie, J. E. Dore, M. González-Dávila, L. Lorenzoni, F. Muller-Karger, J. Olafsson, and J. M. Santana-Casiano.

2014. A time-series view of changing ocean chemistry due to ocean uptake of anthropogenic $\mathrm{CO}_{2}$ and ocean acidification. Oceanography 27(1):126-141. Crossref

Bayne, B. L.

1965. Growth and the delay of metamorphosis of the larvae of Mytilus edulis (L.). Ophelia 2:1-47. Crossref

Bennett, H., J. J. Bell, S. K. Davy, N. S. Webster, and D. S. Francis. 2018. Elucidating the sponge stress response; lipids and fatty acids can facilitate survival under future climate scenarios. Global Chang. Biol. 24:3130-3144. Crossref

Biao, X., D. Zhuhong, and W. Xiaorong.

2004. Impact of the intensive shrimp farming on the water quality of the adjacent coastal creeks from Eastern China. Mar. Pollut. Bull. 48:543-553. Crossref

Bockmon, E. E., and A. G. Dickson.

2015. An inter-laboratory comparison assessing the quality of seawater carbon dioxide measurements. Mar. Chem. 171:36-43. Crossref

Boehme, S. E., C. L. Sabine, and C. E. Reimers.

1998. $\mathrm{CO}_{2}$ fluxes from a coastal transect: a time-series approach. Mar. Chem. 63:49-67. Crossref

Bylenga, C. H., V. J. Cummings, and K. G. Ryan.

2015. Fertilisation and larval development in an Antarctic bivalve, Laternula elliptica, under reduced $\mathrm{pH}$ and elevated temperatures. Mar. Ecol. Prog. Ser. 536:187-201. Crossref

Caldeira, K., and M. E. Wickett.

2003. Anthropogenic carbon and ocean pH. Nature 425:365. Crossref

Cargnelli, L. M., S. J. Griesbach, D. B. Packer, and E. Weissberger. 1999. Essential fish habitat source document: Atlantic surfclam, Spisula solidissima, life history and habitat characteristics. NOAA Tech. Memo. NMFS-NE-142, 13 p.

Chen, B., L. Lin, Z. Ma, T. Zhang, W. Chen, and D. Zou.

2019. Carbon and nitrogen accumulation and interspecific competition in two algae species, Pyropia haitanensis and Ulva lactuca, under ocean acidification conditions. Aquac. Int. 27:721-733. Crossref

Clements, J. C., and H. L. Hunt.

2014. Influence of sediment acidification and water flow on sediment acceptance and dispersal of juvenile soft-shell clams (Mya arenaria L.). J. Exp. Mar. Biol. Ecol. 453:62-69. Crossref 
Clements, J. C., D. Bourque, J. McLaughlin, M. Stephenson, and L. A. Comeau.

2017. Extreme ocean acidification reduces the susceptibility of eastern oyster shells to a polydorid parasite. J. Fish Dis. 40:1573-1585. Crossref

Clements, J. C., L. A. Comeau, C. E. Carver, É. Mayrand, S. Plante, and A. L. Mallet.

2018. Short-term exposure to elevated $\mathrm{pCO}_{2}$ does not affect the valve gaping response of adult eastern oysters, Crassostrea virginica, to acute heat shock under an ad libitum feeding regime. J. Exp. Mar. Biol. Ecol. 506:9-17. Crossref

Crockett, E. L.

1998. Cholesterol function in plasma membranes from ectotherms: membrane-specific roles in adaptation to temperature. Am. Zool. 38:291-304. Crossref

Dickinson, G. H., A. V. Ivanina, O. B. Matoo, H. O. Pörtner, G. Lannig,

C. Bock, E. Beniash, and I. M. Sokolova.

2012. Interactive effects of salinity and elevated $\mathrm{CO}_{2}$ levels on juvenile eastern oysters, Crassostrea virginica. J. Exp. Biol. 215:29-43. Crossref

Dickinson, G. H., O. B. Matoo, R. T. Tourek, I. M. Sokolova, and

E. Beniash.

2013. Environmental salinity modulates the effects of elevated $\mathrm{CO}_{2}$ levels on juvenile hard-shell clams, Mercenaria mercenaria. J. Exp. Biol. 216:2607-2618. Crossref

Dickson, A. G.

1990. Standard potential of the reaction: $\mathrm{AgCl}(\mathrm{s})+12 \mathrm{H}_{2}(\mathrm{~g})=$ $\mathrm{Ag}(\mathrm{s})+\mathrm{HCl}(\mathrm{aq})$, and and the standard acidity constant of the ion $\mathrm{HSO}_{4}^{-}$in synthetic sea water from 273.15 to $318.15 \mathrm{~K}$. J. Chem. Thermodyn. 22:113-127. Crossref

Dickson, A. G., and F. J. Millero.

1987. A comparison of the equilibrium constants for the dissociation of carbonic acid in seawater media. Deep Sea Res. Oceanogr., A 34:1733-1743. Crossref

Doney, S. C., V. J. Fabry, R. A. Feely, and J. A. Kleypas.

2009. Ocean acidification: the other $\mathrm{CO}_{2}$ problem. Annu. Rev. Mar. Sci. 1:169-192. Crossref

Duarte, C. M., I. E. Hendriks, T. S. Moore, Y. S. Olsen, A. Steckbauer,

L. Ramajo, J. Carstensen, J. A. Trotter, and M. McCulloch.

2013. Is ocean acidification an open-ocean syndrome? Understanding anthropogenic impacts on seawater $\mathrm{pH}$. Estuar. Coast. 36:221-236. Crossref

Duarte, C., J. M. Navarro, K. Acuña, R. Torres, P. H. Manríquez,

M. A. Lardies, C. A. Vargas, N. A. Lagos, and V. Aguilera.

2015. Intraspecific variability in the response of the edible mussel Mytilus chilensis (Hupe) to ocean acidification. Estuar. Coast. 38:590-598. Crossref

Ekstrom, J. A., L. Suatoni, S. R. Cooley, L. H. Pendleton, G. G. Waldbusser, J. E. Cinner, J. Ritter, C. Langdon, R. van Hooidonk, D. Gledhill, et al.

2015. Vulnerability and adaptation of US shellfisheries to ocean acidification. Nat. Clim. Chang. 5:207-214. Crossref

Fay, C. W., R. J. Neves, and G. B. Pardue.

1983. Species profiles: life histories and environmental requirements of coastal fishes and invertebrates (mid Atlantic): surf clam. U.S. Fish Wildl. Serv. FWS/OBS-82/ $11.13,23 \mathrm{p}$

Feely, R. A., C. L. Sabine, K. Lee, W. Berelson, J. Kleypas, V. J. Fabry, and F. J. Millero.

2004. Impact of anthropogenic $\mathrm{CO}_{2}$ on the $\mathrm{CaCO}_{3}$ system in the oceans. Science 305:362-366. Crossref

Feely, R. A., S. R. Alin, J. Newton, C. L. Sabine, M. Warner, A. Devol,

C. Krembs, and C. Maloy.

2010. The combined effects of ocean acidification, mixing, and respiration on $\mathrm{pH}$ and carbonate saturation in an urbanized estuary. Estuar. Coast. Shelf Sci. 88:442-449. Crossref
Friedland, K. D., R. E. Morse, J. P. Manning, D. C. Melrose, T. Miles, A. G. Goode, D. C. Brady, J. T. Kohut, and E. N. Powell.

2020. Trends and change points in surface and bottom thermal environments of the US Northeast Continental Shelf Ecosystem. Fish. Oceanogr. 29:396-414. Crossref

Gazeau, F., L. M. Parker, S. Comeau, J.-P. Gattuso, W. A. O'Connor, S. Martin, H.-O. Pörtner, and P. M. Ross.

2013. Impacts of ocean acidification on marine shelled molluscs. Mar. Biol. 160:2207-2245. Crossref

Gledhill, D. K., M. M. White, J. Salisbury, H. Thomas, I. Mlsna, M. Liebman, B. Mook, J. Grear, A. C. Candelmo, R. C. Chambers, et al.

2015. Ocean and coastal acidification off New England and Nova Scotia. Oceanography 28(2):182-197. Crossref

Gobler, C. J., and S. C. Talmage.

2014. Physiological response and resilience of early lifestage Eastern oysters (Crassostrea virginica) to past, present and future ocean acidification. Conserv. Physiol. 2:cou004. Crossref

Goldberg, R.

1989. Biology and culture of the surf clam. In Clam mariculture in North America (J. Manzi and M. Castagna, eds.), p. 263-276. Elsevier Sci. Publ., Amsterdam, Netherlands.

Goldsmith, K. A., S. Lau, M. E. Poach, G. P. Sakowicz, T. M. Trice, C. R. Ono, J. Nye, E. H. Shadwick, K. A. StLaurent, and G. K. Saba.

2019. Scientific considerations for acidification monitoring in the U.S. Mid-Atlantic region. Estuar. Coast. Shelf Sci. 225:106189. Crossref

Green, M. A., M. E. Jones, C. L. Boudreau, R. L. Moore, and B. A. Westman.

2004. Dissolution mortality of juvenile bivalves in coastal marine deposits. Limnol. Oceanogr. 49:727-734. Crossref

Green, M. A., G. G. Waldbusser, S. L. Reilly, K. Emerson, and S. O'Donnell.

2009. Death by dissolution: sediment saturation state as a mortality factor for juvenile bivalves. Limnol. Oceanogr. 54:1037-1047. Crossref

Green, M. A., G. G. Waldbusser, L. Hubazc, E. Cathcart, and J. Hall.

2013. Carbonate mineral saturation state as the recruitment cue for settling bivalves in marine muds. Estuar. Coast. 36:18-27. Crossref

Hare, M. P., and J. R. Weinberg.

2005. Phylogeography of surfclams, Spisula solidissima, in the western North Atlantic based on mitochondrial and nuclear DNA sequences. Mar. Biol. 146:707-716. Crossref

Hare, M. P., J. Weinberg, O. Peterfalvy, and M. Davidson.

2010. The "southern" surfclam (Spisula solidissima similis) found north of its reported range: a commercially harvested population in Long Island Sound, New York. J. Shellfish Res. 29:799-807. Crossref

Hare, J. A., W. E. Morrison, M. W. Nelson, M. M. Stachura, E. J. Teeters, R. B. Griffis, M. A. Alexander, J. D. Scott, L. Alade, R. J. Bell, et al.

2016. A vulnerability assessment of fish and invertebrates to climate change on the Northeast U.S. continental shelf. PLoS ONE 11(2):e0146756. Crossref

Hartin, C. A., B. Bond-Lamberty, P. Patel, and A. Mundra.

2016. Ocean acidification over the next three centuries using a simple global climate carbon-cycle model: projections and sensitivities. Biogeosciences 13:4329-4342. Crossref

Hönisch, B., A. Ridgwell, D. N. Schmidt, E. Thomas, S. J. Gibbs, A. Sluijs, R. Zeebe, L. Kump, R. C. Martindale, S. E. Greene, et al. 2012. The geological record of ocean acidification. Science 335:1058-1063. Crossref 
IPCC (Intergovernmental Panel on Climate Change).

2014. Climate change 2014: synthesis report. Contribution of working groups I, II and III to the fifth assessment report of the Intergovernmental Panel on Climate Change (Core writing team, R. K. Pachauri and L. A. Meyer, eds.), 151 p. ICPP, Geneva, Switzerland. [Available from website.]

Kusumi, A., W. K. Subczynski, M. Pasenkiewicz-Gierula, J. S. Hyde, and H. Merkle.

1986. Spin-label studies on phosphatidylcholine-cholesterol membranes: effects of alkyl chain length and unsaturation in the fluid phase. Biochim. Biophys. Acta 854:307-317. Crossref

Lannig, G., S. Eilers, H. O. Pörtner, I. M. Sokolova, and C. Bock.

2010. Impact of ocean acidification on energy metabolism of oyster, Crassostrea gigas - changes in metabolic pathways and thermal response. Mar. Drugs 8:2318-2339. Crossref

Li, W., and K. Gao.

2012. A marine secondary producer respires and feeds more in a high $\mathrm{CO}_{2}$ ocean. Mar. Pollut. Bull. 64:699-703. Crossref

Loosanoff, V. L., and H. C. Davis.

1963. Rearing of bivalve mollusks. Adv. Mar. Biol. 1:1-136. Crossref

Mehrbach, C., C. H. Culberson, J. E. Hawley, and R. M. Pytkowicx. 1973. Measurement of the apparent dissociation constants of carbonic acid in seawater at atmospheric pressure. Limnol. Oceanogr. 18:897-907. Crossref

Meseck, S. L., R. Mercaldo-Allen, C. Kuropat, P. Clark, and

R. Goldberg.

2018. Variability in sediment-water carbonate chemistry and bivalve abundance after bivalve settlement in Long Island Sound, Milford, Connecticut. Mar. Pollut. Bull. 135:165-175. Crossref

Miller, A. W., A. C. Reynolds, C. Sobrino, and G. F. Riedel. 2009. Shellfish face uncertain future in high $\mathrm{CO}_{2}$ world: influence of acidification on oyster larvae calcification and growth in estuaries. PLoS ONE 4(5):e5661. Crossref

Miller, G. M., S.-A. Watson, M. I. McCormick, and P. L. Munday.

2013. Increased $\mathrm{CO}_{2}$ stimulates reproduction in a coral reef fish. Global Chang. Biol. 19:3037-3045. Crossref

Miller, S. H., D. L. Breitburg, R. B. Burrell, and A. G. Keppel. 2016. Acidification increases sensitivity to hypoxia in important forage fishes. Mar. Ecol. Prog. Ser. 549:1-8. Crossref

Munroe, D. M., D. A. Narváez, D. Hennen, L. Jacobson, R. Mann,

E. E. Hofmann, E. N. Powell, and J. M. Klinck.

2016. Fishing and bottom water temperature as drivers of change in maximum shell length in Atlantic surfclams (Spisula solidissima). Estuar. Coast. Shelf Sci. 170:112-122. Crossref

NEFSC (Northeast Fisheries Science Center).

2017. 61st northeast regional stock assessment workshop (61st SAW) assessment report. Northeast Fish. Sci. Cent. Ref. Doc. 17-05, 466 p. [Available from website.]

Pace, D. A., A. G. Marsh, P. K. Leong, A. J. Green, D. Hedgecock, and D. T. Manahan.

2006. Physiological bases of genetically determined variation in growth of marine invertebrate larvae: a study of growth heterosis in the bivalve Crassostrea gigas. J. Exp. Mar. Biol. Ecol. 335:188-209. Crossref

Parker, L. M., P. M. Ross, and W. A. O'Connor.

2011. Populations of the Sydney rock oyster, Saccostrea glomerata, vary in response to ocean acidification. Mar. Biol. 158:689-697. Crossref

Parrish, C. C.

1999. Determination of total lipid, lipid classes, and fatty acids in aquatic samples. In Lipids in freshwater ecosystems (M. T. Arts and B. C. Wainman, eds.), p. 4-20. Springer, New York.
Parsons, P. A.

2001. The hormetic zone: an ecological and evolutionary perspective based upon habitat characteristics and fitness selection. Q. Rev. Biol. 76:459-467. Crossref

Pernet, F., R. Tremblay, C. Gionet, and T. Landry.

2006. Lipid remodeling in wild and selectively bred hard clams at low temperatures in relation to genetic and physiological parameters. J. Exp. Biol. 209:4663-4675. Crossref

Pernet, F., R. Tremblay, L. Comeau, and H. Guderley.

2007. Temperature adaptation in two bivalve species from different thermal habitats: energetics and remodelling of membrane lipids. J. Exp. Biol. 210:2999-3014. Crossref

Perry, D. M., D. H. Redman, J. C. Widman Jr., S. Meseck, A. King, and J. J. Pereira.

2015. Effect of ocean acidification on growth and otolith condition of juvenile scup, Stenotomus chrysops. Ecol. Evol. 5:4187-4196. Crossref

Pierrot, D., E. Lewis, and D. W. R. Wallace.

2006. MS Excel program developed for $\mathrm{CO} 2$ system calculations. U.S. Dep. Energy, Oak Ridge Natl. Lab., Carbon Dioxide Inf. Anal. Cent. ORNL/CDIAC-105a. [Available from website.]

Pörtner, H. O., M. Langenbuch, and B. Michaelidis.

2005. Synergistic effects of temperature extremes, hypoxia, and increases in $\mathrm{CO}_{2}$ on marine animals: from earth history to global change. J. Geophys. Res. Oceans 110:C09S10. Crossref

Pousse, E., M. E. Poach, D. H. Redman, G. Sennefelder, L. E. White,

J. M. Lindsay, D. Munroe, D. Hart, D. Hennen, M. S. Dixon, et al. 2020. Energetic response of Atlantic surfclam Spisula solidissima to ocean acidification. Mar. Pollut. Bull. 161:111740. Crossref

Powell, E. N., E. A. Bochenek, J. M. Klinck, and E. E. Hofmann.

2002. Influence of food quality and quantity on the growth and development of Crassostrea gigas larvae: a modeling approach. Aquaculture 210:89-117. Crossref

Rasband, W. S.

2015. ImageJ. U.S. Natl. Inst. Health, Bethesda, MD [Available from website, accessed June 2015.]

Riebesell, U., V. J. Fabry, L. Hansson, and J.-P. Gattuso (eds.).

2011. Guide to best practices for ocean acidification research and data reporting, 260 p. Publ. Off. Eur. Union, Luxembourg, Luxemburg. [Available from website.]

Saba, G. K., K. A. Goldsmith, S. R. Cooley, D. Grosse, S. L. Meseck, A. W. Miller, B. Phelan, M. Poach, R. Rheault, K. St.Laurent, et al.

2019. Recommended priorities for research on ecological impacts of ocean and coastal acidification in the U.S.

Mid-Atlantic. Estuar. Coast. Shelf Sci. 225:106188. Crossref

Siedlecki, S. A., J. Salisbury, D. K. Gledhill, C. Bastidas, S. Meseck, K. McGarry, C. W. Hunt, M. Alexander, D. Lavoie, Z. A. Wang, et al.

2021. Projecting ocean acidification impacts for the Gulf of Maine to 2050: new tools and expectations. Elem. Sci. Anth. 9(1):0006. Crossref

Snyder, J. T., M. M. Whitney, H. G. Dam, M. W. Jacobs, and H. Baumann.

2019. Citizen science observations reveal rapid, multidecadal ecosystem changes in eastern Long Island Sound. Mar. Environ. Res. 146:80-88. Crossref

Talmage, S. C., and C. J. Gobler.

2009. The effects of elevated carbon dioxide concentrations on the metamorphosis, size, and survival of larval hard clams (Mercenaria mercenaria), bay scallops (Argopecten irradians), and Eastern oysters (Crassostrea virginica). Limnol. Oceanogr. 54:2072-2080. Crossref 
Thomsen, J., and F. Melzner.

2010. Moderate seawater acidification does not elicit longterm metabolic depression in the blue mussel Mytilus edulis. Mar. Biol. 157:2667-2676. Crossref

Thomsen, J., L. S. Stapp, K. Haynert, H. Schade, M. Danelli,

G. Lannig, K. M. Wegner, and F. Melzner.

2017. Naturally acidified habitat selects for ocean acidification-tolerant mussels. Sci. Adv. 3:e1602411. Crossref

Thor, P., and E. O. Oliva.

2015. Ocean acidification elicits different energetic responses in an Arctic and a boreal population of the copepod Pseudocalanus acuspes. Mar. Biol. 162:799-807. Crossref

Turk, M., V. Montiel, D. Žigon, A. Plemenitaš, and J. Ramos.

2007. Plasma membrane composition of Debaryomyces hansenii adapts to changes in $\mathrm{pH}$ and external salinity. Microbiology 153:3586-3592. Crossref

Uppström, L. R.

1974. The boron/chlorinity ratio of deep-sea water from the Pacific Ocean. Deep-Sea Res. Oceanogr. Abstr. 12:161-162. Crossref

Waldbusser, G. G., and J. E. Salisbury.

2014. Ocean acidification in the coastal zone from an organism's perspective: multiple system parameters, frequency domains, and habitats. Annu. Rev. Mar. Sci. 6:221-247. Crossref

Waldbusser, G. G., B. Hales, C. J. Langdon, B. A. Haley, P. Schrader,

E. L. Brunner, M. W. Gray, C. A. Miller, I. Gimenez, and

G. Hutchinson.

2015. Ocean acidification has multiple modes of action on bivalve larvae. PLoS ONE 10(6):e0128376. Crossref

Waldbusser, G. G., M. W. Gray, B. Hales, C. J. Langdon, B. A. Haley,

I. Gimenez, S. R. Smith, E. L. Brunner, and G. Hutchinson.

2016. Slow shell building, a possible trait for resistance to the effects of acute ocean acidification. Limnol. Oceanogr. 61:1969-1983. Crossref

Walker, R. L., and F. X. O'Beirn.

1996. Embryonic and larval development of Spisula solidissima similis (Say, 1822) (Bivalvia: Mactridae). Veliger 39:60-64

Wang, $\mathrm{H}$.

2016. On shelf-slope water mass exchanges near Washington Canyon and Norfolk Canyon in the Mid-Atlantic Bight. M.S. thesis, 176 p. Coll. William Mary, Williamsburg, VA. [Available from website.]

Wang, H., X. Hu, W.-J. Cai, and B. Sterba-Boatwright.

2017. Decadal $f \mathrm{CO}_{2}$ trends in global ocean margins and adjacent boundary current-influenced areas. Geophys. Res. Lett. 44:8962-8970. Crossref
Wang, Z. A., R. Wanninkhof, W.-J. Cai, R. H. Byrne, X. Hu,

T.-H. Peng, and W.-J. Huang.

2013. The marine inorganic carbon system along the Gulf of Mexico and Atlantic coasts of the United States: insights from a transregional coastal carbon study. Limnol. Oceanogr. 58:325-342. Crossref

Wanninkhof, R., L. Barbero, R. Byrne, W.-J. Cai, W.-J. Huang,

J.-Z. Zhang, M. Baringer, and C. Langdon.

2015. Ocean acidification along the Gulf Coast and East Coast of the USA. Cont. Shelf Res. 98:54-71. Crossref

Weinberg, J. R.

2005. Bathymetric shift in the distribution of Atlantic surfclams: response to warmer ocean temperature. ICES J. Mar. Sci. 62:1444-1453. Crossref

Weinberg, J. R., and T. E. Helser.

1996. Growth of the Atlantic surfclam, Spisula solidissima, from Georges Bank to the Delmarva Peninsula, USA. Mar. Biol. 126:663-674. Crossref

White, M. M., D. C. McCorkle, L. S. Mullineaux, and A. L. Cohen.

2013. Early exposure of bay scallops (Argopecten irradians) to high $\mathrm{CO}_{2}$ causes a decrease in larval shell growth. PLoS ONE 8(4):e61065. Crossref

Xu, Y.-Y., W.-J. Cai, Y. Gao, R. Wanninkhof, J. Salisbury, B. Chen,

J. J. Reimer, S. Gonski, and N. Hussain.

2017. Short-term variability of aragonite saturation state in the central Mid-Atlantic Bight. J. Geophys. Res. Oceans 122:4274-4290. Crossref

Young, C. S., and C. J. Gobler.

2018. The ability of macroalgae to mitigate the negative effects of ocean acidification on four species of North Atlantic bivalve. Biogeosciences 15:6167-6183. Crossref

Zeebe, R. E.

2012. History of seawater carbonate chemistry, atmospheric $\mathrm{CO}_{2}$, and ocean acidification. Annu. Rev. Earth Planet. Sci. 40:141-165. Crossref

Zeebe, R. E., A. Ridgwell, and J. C. Zachos.

2016. Anthropogenic carbon release rate unprecedented during the past 66 million years. Nat. Geosci. 9:325-329. Crossref

Zhang, X., D. Haidvogel, D. Munroe, E. N. Powell, J. Klinck, R. Mann, and F. S. Castruccio.

2015. Modeling larval connectivity of the Atlantic surfclams within the Middle Atlantic Bight: model development, larval dispersal and metapopulation connectivity. Estuar. Coast. Shelf Sci. 153:38-53. Crossref

Zhang, X., D. Munroe, D. Haidvogel, and E. N. Powell.

2016. Atlantic surfclam connectivity within the Middle Atlantic Bight: mechanisms underlying variation in larval transport and settlement. Estuar. Coast. Shelf Sci. 173:65-78. Crossref 